\title{
Influence of Tuberculin Testing on the Waning of Postvaccination Allergy
}

\author{
S.J. Kim, C.D. Park, Y.P. Hong and M.K. Kang \\ The Korean Institute of Tuberculosis, The Korean National Tuberculosis Association, Seoul, Korea
}

=국문초록 $=$

튜벨쿠린검사가 BCG 유도 튜벨쿠린 피부반응에 미치는 영향

대한결핵헙회 결핵연구원

김상재• 박종달* - 홍영표 - 강미경

\begin{abstract}
국민학교 아동을 대상으로 BCG접종에 의한 튜벨쿠린 피부반응력 유도에 대해 관찰하고 그리고 시 간경과에 따른 튜벨쿠린 반응력의 감소와 튜벨쿠린검사로 인한 반응력의 회복에 대해 관찰하였다. 국내에서 생산된 냉동건조 $\mathrm{BCG}$ (French균주 $1173 \mathrm{p} 2$ )를 튜벨쿠린반응 음성인 국민학교 1학년 아동 (768명)에게 접종하고 9 주후에 일부 아동에게 튜벨쿠린검사를 실시한 결과 $78.3 \%$ 의 아동이 $10 \mathrm{~mm}$ 이상의 경결반응을 나타내었고 경결크기의 평균치는 $12.6 \mathrm{~mm}$ 였다. 그러나 BCG접종 1 년, 3 년 또는 5 년후에 실시한 검사에서는 양성반응자가 각각 $42.1 \%, 29.9 \%$ 및 $27.8 \%$ 로 감소했고 경결크기도 각 각 $7.8 \mathrm{~mm}, 6.8 \mathrm{~mm}$ 및 $5.8 \mathrm{~mm}$ 로 작아졌다. 그러나 튜벨쿠린검사를 한번이상 받았던 아동에서는 그 와 같은 감소현상이 크게 방지되어 양성반응자가 전에 검사를 받은 바 없는 아동의 3년 또는 5년후 양성반응자의 배에 가까웠다. 전에 튜벨쿠린검사를 1 희 실시한 아동보다 2 회 실시한 아동에서 양성 반응자가 더 많고 그리고 모든 검사에서 음성반응을 나타내는 아동은 접종후 첫 튜벨쿠린검사를 실 시하기 까지의 기간이 길수록 그 수가 더 많았다. 튜벨쿠린검사를 1 2회 실시해도 양성반응자가 접 종후 9 주에 실시했을 때 만큼 많아지지 않는 점으로 보아 일부아동의 반응은 튜벨쿠린검사를 받아 도 반응이 회복되지 않거나 회복되어도 곧 다시 감소하는 것으로 본다.
\end{abstract}

\section{Introduction}

The waning of the BCG induced tuberculin hypersensitivity with a lapse of time and its restoration by tuberculin testing was observed by Magnus ${ }^{1)}$ for the first time and subsequently by many others in both human and animals ${ }^{2 \sim 11}$. The tuberculin reaction reaches its maximum usually at 6 weeks after vaccination and lasts for a month before it starts to wane,

\footnotetext{
*근로복지공사 동해 산재병원
}

regardless of the $B C G$ strains used to vaccinate children $^{4,10)}$. Waning occurred within 6 months and seemed to continue for the first few years ${ }^{6,7)}$. This waning, however, could be prevented by tuberculin testing as early as 10 weeks after vaccination ${ }^{7}$.

The marked restoration of tuberculin hypersensitivity is usually observed when the interim tests are given after 6 months or more ${ }^{6,7)}$. Such booster effects could be observed as early as 3 days after tuberculin tests ${ }^{4)}$.

As such restoration of tuberculin hypersensitivity does not necessarily mean a concomitant increase in 
the acquired resistance, the revaccination policy based on the tuberculin allergy was considered as irrational ${ }^{3,7}$.

In this study we have investigated the development and waning of BCG induced tuberculin hypersensitivity and the restoration or prevention of waning by repeated tuberculin testing in Korean children.

\section{Materials and Methods}

This prospective study was started in 1982 in recently vaccinated children of 3 primary schools in Seoul city. The study population was made up of 768 first grade schoolchildren (male $=389$ ) (mostly aged 6 years and a few 7 years) who showed reactions of less than $6 \mathrm{~mm}$ to the tuberculin test before $\mathrm{BCG}$ vaccination. All the children were vaccinated with 0 . $1 \mathrm{mg}$ of the freeze-dried BCG vaccine (French 1173 p2) and then divided into 5 groups according to a random procedure, which were again tested with 1 TU of tuberculin RT23 with tween. Group A children were tested at 9 weeks, 3, and/or 5 years after vaccination; group B after 1, 3, and/or 5 years; group $\mathrm{C}$ after 2, 3, and 5 years; group D after 3 and 5 years; group $\mathrm{E}$ after 5 years. The tuberculin test sites were the middle and lower parts of the left forearm and the middle part of the right forearm. The same site was never used more than once.

\section{Results}

The results of the study are summarized in table 1 and in the accompanying figures. The BCG vaccination rendered $10 \mathrm{~mm}$ or more tuberculin reactions in $78.3 \%$ of children who showed a negative reaction before vaccination. The mean indurations before and 9 weeks after BCG vaccination were 1.1 and 12 . $6 \mathrm{~mm}$. The postvaccination allergy significantly wanes thereafter, showing $7.8 \mathrm{~mm}, 8.3 \mathrm{~mm}, 6.8 \mathrm{~mm}$ or

Table 1. Tuberculin Reaction at the Various Times after BCG Vaccination and According to the History of Interim Tuberculin Test

\begin{tabular}{|c|c|c|c|c|c|c|c|c|}
\hline \multirow{2}{*}{$\begin{array}{l}\text { BCG } \\
\text { vaccina- } \\
\text { tion }\end{array}$} & \multicolumn{3}{|c|}{$\begin{array}{l}\text { Tuberculin tests after } \\
\text { vaccination }\end{array}$} & \multirow{2}{*}{$\begin{array}{l}\text { Number of } \\
\text { entries }\end{array}$} & \multirow{2}{*}{$\begin{array}{l}\text { Mean } \\
\text { induration } \\
\text { and SD }\end{array}$} & \multirow{2}{*}{$\begin{array}{l}\geqslant 6 \mathrm{~mm} \\
\text { reactors } \\
(\%)\end{array}$} & \multirow{2}{*}{$\begin{array}{l}\geqslant 10 \mathrm{~mm} \\
\text { reactors } \\
(\%)\end{array}$} & \multirow{2}{*}{$\begin{array}{l}\text { Mean } \\
\text { scar and } \\
\text { SD }\end{array}$} \\
\hline & $1 \mathrm{st}$ & 2nd & $3 r d$ & & & & & \\
\hline No & & & & 768 (U) & $1.1 \pm 1.6$ & 0.0 & 0.0 & \\
\hline & $9 w$ & & & 203 (A) & $12.6 \pm 4.4$ & 89.7 & 78.3 & $5.2 \pm 1.4$ \\
\hline & $1 Y$ & & & 190 (B) & $7.8 \pm 6.2$ & 54.2 & 42.1 & $5.9 \pm 1.2$ \\
\hline & $2 Y$ & & & 142 (C) & $8.3 \pm 6.8$ & $\$ 5.6$ & 46.5 & $6.5 \pm 1.4$ \\
\hline & $3 Y$ & & & 197 (D) & $6.8 \pm 5.8$ & 47.7 & 29.9 & $6.2 \pm 1.4$ \\
\hline & $5 Y$ & & & $36(E)$ & $5.8 \pm 6.1$ & 38.9 & 27.8 & \\
\hline & $9 w$ & $3 Y$ & & $117(F)$ & $10.3 \pm 6.3$ & 70.9 & 59.0 & \\
\hline \multirow[t]{8}{*}{ Yes } & $1 \mathrm{Y}$ & $3 Y$ & & $118 \quad(G)$ & $10.6 \pm 6.2$ & 74.6 & 60.2 & \\
\hline & $2 Y$ & $3 Y$ & & $107(\mathrm{H})$ & $10.8 \pm 6.7$ & 70.1 & 56.1 & \\
\hline & $9 w$ & $5 Y$ & & $26(1)$ & $5.8 \pm 5.8$ & 42.3 & 23.1 & \\
\hline & $1 \mathrm{Y}$ & $5 Y$ & & $18(\mathrm{~J})$ & $8.2 \pm 8.2$ & 50.0 & 44.4 & \\
\hline & $3 Y$ & $5 Y$ & & $113(\mathrm{~K})$ & $8.0 \pm 6.6$ & 58.4 & 40.7 & \\
\hline & $9 w$ & $3 Y$ & $5 Y$ & $58(\mathrm{~L})$ & $9.7 \pm 6.2$ & 74.1 & 56.9 & \\
\hline & $1 \mathrm{Y}$ & $3 Y$ & $5 Y$ & $66(M)$ & $10.8 \pm 6.6$ & 77.3 & 65.2 & \\
\hline & $2 Y$ & $3 Y$ & $5 Y$ & $58(\mathrm{~N})$ & $9.5 \pm 7.0$ & 69.0 & 53.4 & \\
\hline
\end{tabular}

* $\mathrm{W}=$ week, $\mathrm{Y}=$ year

** The characters in parentheses indicate group designation. 
$5.8 \mathrm{~mm}$ of mean induration at $1,2,3$ or 5 years after vaccination respectively. The $10 \mathrm{~mm}$ or more reactions remained $42.1 \%$ after 1 year, $46.5 \%$ after 2 years, $29.9 \%$ after 3 years and $27.8 \%$ after 5 years as seen in table 1 and figure 2 . As shown in figure 1 , a uniform dose $(0.1 \mathrm{mg})$ of $B C G$ vaccine elicited a fairly uniform postvaccination allergy after 9 weeks and thus the distribution of these reactions showed a more or less unimodal curve, which, however, changed considerably after 1 or more years. Repeated tuberculin tests after 3 and/or 5 years revealed that the tuberculin sensitivity has been returned or prevented from waning in a considerable number of children. While the mean induration and $10 \mathrm{~mm}$ or more reactions in those not tested previously were 6 . $8 \mathrm{~mm}$ and $29.9 \%$ respectively after 3 years, the children tested at 9 weeks, 1 or 2 years after vaccination showed $10.3-10.8 \mathrm{~mm}$ of mean induration and a 10 $\mathrm{mm}$ or more reaction in $70.1-74.6 \%$. It is of interest that there are no differences in the mean reaction size and in the number of $10 \mathrm{~mm}$ or more reactions in those tested at the different intervals between the first (interim) and last (3 years) tests after vaccination. After 5 years, however, 9 week interim tests did not restore or prevent waning of tuberculin sensitivity (remained only $23.1 \%$ of strong reaction) and 1 or 3 year interim tests restored reactivity to some extent, showing $44.4 \%$ or $40.7 \%$ of strong reaction.

Many of the positive reactors at 9 weeks after vaccination become negative after 3 or 5 years although such negative conversion was much less frequent in those given the interim tests after 1, 2 or 3 years as seen in table 2 . In those tested at 9 weeks after vaccination, $23.9 \%$ showed reactions which had decreased by $5 \mathrm{~mm}$ or more on the second tests after 3 years, while in those tested after 1 or 2 years a decreased reaction was found only in $7.6 \%$ or $3.7 \%$ respectively. On the contrary, reactions with a $5 \mathrm{~mm}$ or more increase was much more common among those given the interim tests after 1 or 2 years (31.4 $\%$ and $23.4 \%$ respectively) than among those tested after 9 weeks $(7.7 \%)$, as seen in table 2 . When the

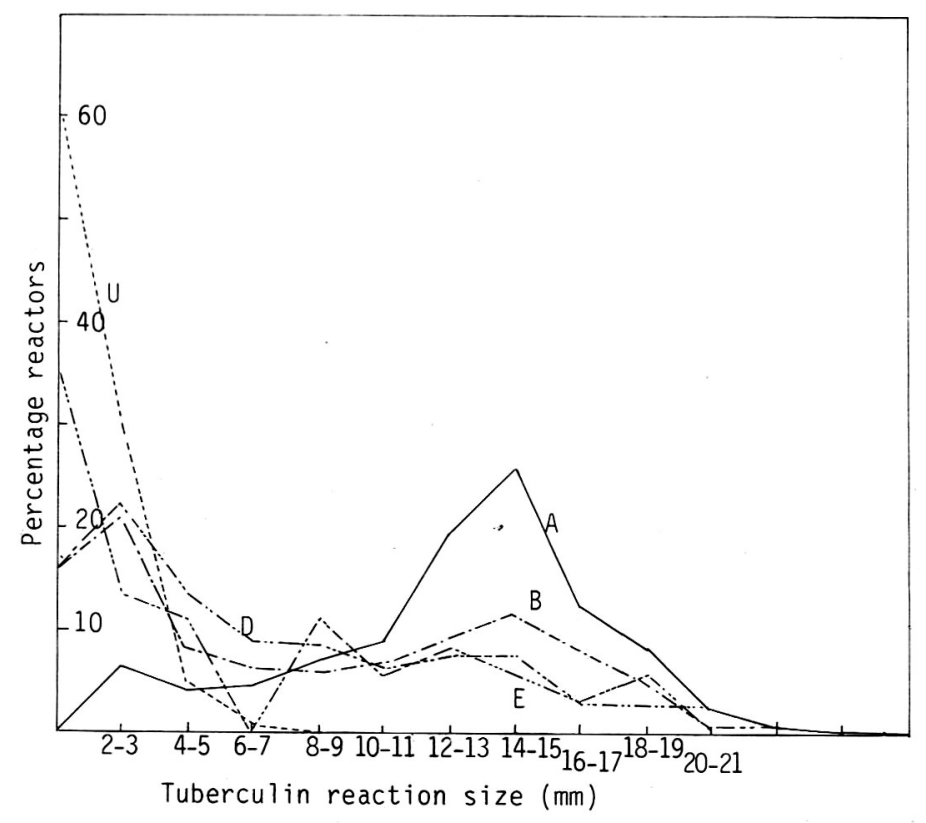

Fig. 1. Distribution of children by the size of reaction to tuberculin before and after $B C G$ vaccination. For explanation of group designations (A, B, D, E, U), see Table 1 . 
second tests were done after $\bar{j}$ years, decreased reactions in those given the interim tests at 9 weeks, 1 or 3 years after vaccination were found in $57.7 \%$, $16.7 \%$ or $4.4 \%$ respectively.

The negative reactions (less than $5 \mathrm{~mm}$ reaction) on both first and second tests steadily increased as the intervals between the time of vaccination and first interim tests widened. Merely $5.1 \%$ of negative reactions were found in those given the interim tests at 9 weeks and the last tests after 3 years, but were $15.3 \%$ and $23.4 \%$ in those given the interim tests at 1 and 2 years after vaccination respectively (Table 2 ). Additional increase of negative reactions were found when the last tests were performed after 5 years.

The strong reactions were found more frequenlty in those given two interim tests than in those given one interim test. Five millimeter or more increased reactions in the last tests were $12.0 \%$ in those given the first test at 9 weeks after vaccination and $31.8 \%$ or $25.9 \%$ in those given the first test after 1 or 2 years respectively. Decreased reaction occurred in $41.4 \%$, $22.7 \%$ or $25.9 \%$ of those given the first interim tests at 9 weeks, 1 or 2 years after vaccination respectively. Tuberculin reactions which decreased in the second test but increased again in the last test were found more often among those given the first interim test at 9 weeks after vaccination. On the contrary, reactions which increased in the second test but decreased again in the last test were found more often among those given the first test at 1 or 2 years after vaccination. Here again the longer intervals from the time of vaccination to the first interim

Table 2. Change of the BCG Induced Tuberculin Reaction by Interim Tuberculin Tests

\begin{tabular}{|c|c|c|c|c|}
\hline \multirow[b]{2}{*}{ First tests } & \multirow{2}{*}{$\begin{array}{c}\text { Number of } \\
\text { entries }\end{array}$} & \multicolumn{2}{|c|}{ Second tests } & \multirow{2}{*}{$\begin{array}{c}<5 \mathrm{~mm} \text { in both } \\
\text { first and } \\
\text { last tests }\end{array}$} \\
\hline & & $\begin{array}{l}\geqslant 5 \mathrm{~mm} \\
\text { decrease }\end{array}$ & $\begin{array}{l}\geqslant 5 \mathrm{~mm} \\
\text { increase }\end{array}$ & \\
\hline \multicolumn{5}{|c|}{ after 3 years } \\
\hline At 9 weeks & 117 & $28(23.9)$ & $9(7.7)$ & $6(5.1)$ \\
\hline At 1 year & 118 & $9(7.6)$ & $37(31.4)$ & $18(15.3)$ \\
\hline At 2 years & 107 & $4(3.7)$ & $25(23.4)$ & $25(23.4)$ \\
\hline \multicolumn{5}{|c|}{ after 5 years } \\
\hline At 9 weeks & 26 & 15 (57.7) & $2(7.7)$ & $4(15: 4)$ \\
\hline At 1 year & 18 & $3(16.7)$ & $2(11.1)$ & $6(33.3)$ \\
\hline At 3 years & 113 & $5(4.4)$ & $22(19.5)$ & $36(31.9)$ \\
\hline
\end{tabular}

* The numbers in parentheses are per cent.

Table 3. Change of BCG-Induced Tuberculin Reaction by Two Interim Tests

\begin{tabular}{|c|c|c|c|c|c|c|c|c|}
\hline \multicolumn{3}{|c|}{ Tuberculin tests } & \multirow{2}{*}{$\begin{array}{l}\text { Number of } \\
\text { entries }\end{array}$} & \multicolumn{4}{|c|}{ Skin reaction patterns } & \multirow[b]{2}{*}{$\begin{array}{c}\text { Negative } \\
\text { in all } 3 \\
\text { tests }\end{array}$} \\
\hline $1 \mathrm{st}$ & $2 n d$ & $3 r d$ & & 1 & RI & RD & D & \\
\hline $9 W$ & $3 Y$ & $5 Y$ & $58(100.0)$ & $7(12.0)$ & $7(12.0)$ & $3(5.3)$ & $21(36.2)$ & $1(1.7)$ \\
\hline $1 \mathrm{Y}$ & $3 Y$ & $5 Y$ & $66(100.0)$ & $21(31.8)$ & $4(6.1)$ & $10(15.2)$ & $5(7.6)$ & $6(9.1)$ \\
\hline $2 \mathrm{Y}$ & $3 Y$ & $5 Y$ & $58(100.0)$ & $15(25.9)$ & $2(3.4)$ & $9(15.5)$ & $6(10.3)$ & $11(19.0)$ \\
\hline
\end{tabular}

* $\mathrm{I}=$ increased $5 \mathrm{~mm}$ or more. $\mathrm{RI}=$ decreased $5 \mathrm{~mm}$ or more in the second test but increased again in the last test. $R D=$ increased in the second test but decreased in the last test. $D=$ decreased. $W=$ week. $Y=$ year.

** Numbers in parentheses indicate per cent. 
testing, the more negative reactions in all 3 sequential tests found (Table 3).

Absence of BCG scar or less than $3 \mathrm{~mm}$ scars were found in only 4 out of 768 vaccinated children. The scar size was somewhat larger beyond 9 weeks after vaccination. Mean scar size at 9 weeks was $5.2 \mathrm{~mm}$ and $5.9 \mathrm{~mm}$ at 1 year, $6.5 \mathrm{~mm}$ at 2 years and $6.2 \mathrm{~mm}$ at 3 years after vaccination as seen in Table 1.

\section{Discussion}

If the continuous antigenic stimulation does not exist, the induced immune response may wane as the time goes by. Since an earlier retrospective study

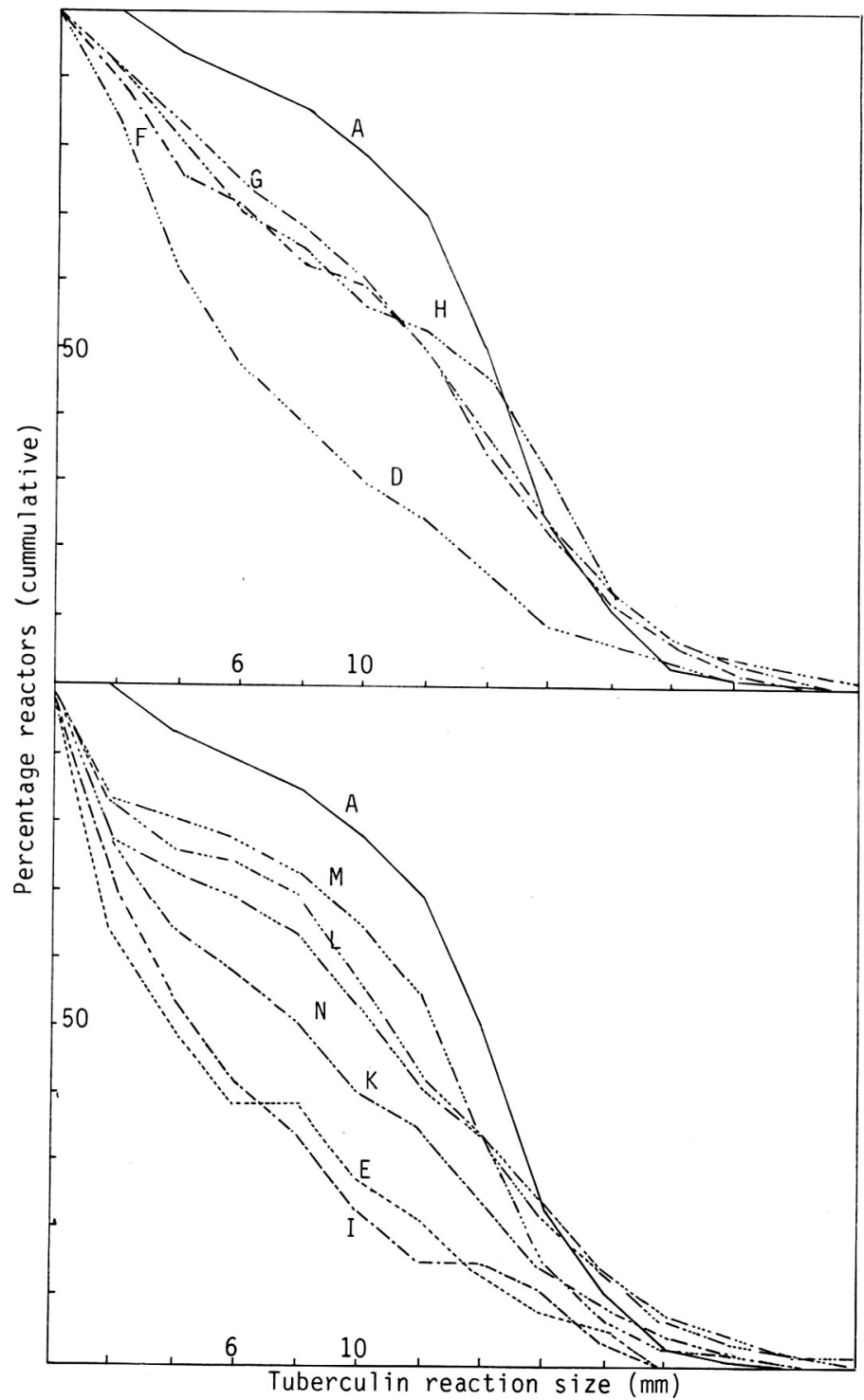

Fig. 2. Cummulative distribution of tuberculin reaction in children after BCG vaccination and in those tested previously after vaccination. For explanation of group designations ( $A, D, E, F, G, H, I, K, L, M, N)$, see Table 1. 
had shown that tuberculin reaction is significantly larger in children tested for the second time after vaccination than in those tested for the first time, many investigators confirmed the waning of BCG induced tuberculin hypersensitivity in both human and animals and its restoration by interim tuberculin tests ${ }^{1 \sim 11}$.

In guinea pigs, the maximum tuberculin reaction usually appears around 6 weeks after BCG vaccination and it lasts for about a month before it starts to wane ${ }^{4}$. It is therefore general practice to test the postvaccination allergy at 9 or 10 weeks after vaccination.

The mean induration of $12.6 \mathrm{~mm}$ and $78.3 \%$ of 10 $\mathrm{mm}$ or more reactors at 9 weeks after vaccination, which were observed in this study, seems to be less satisfactory when compared with those of the other studies $^{3,6,7)}$. Whether it has been resulted from the poor potency of vaccine or technical incompetency in vaccination and tuberculin testing or the use of weak dose of tuberculin (1 TU instead of 2 or $5 \mathrm{TU}$ ) is not known.

The tuberculin hypersensitivity wanes quickly and continues to wane after 5 years at which only $27.8 \%$ of $10 \mathrm{~mm}$ or more reactors are left. Decrease in the number of $10 \mathrm{~mm}$ or more reactions after 1 year is 46 $\%$ less that at 9 weeks and this figure seems to be higher than that $(28 \%)$ of Olakowski's finding ${ }^{7)}$. The waning was noticed even at 6 months after vaccination $^{7)}$ and in one study it was found to continue up to 2.5 years after vaccination but not thereafter ${ }^{6}$. Such waning for the first few years after vaccination could be prevented by interim tuberculin tests as early as 9 weeks after vaccination as it was found in this study or 10 weeks in some other studies $^{3,7)}$ or could be restored even after 4 years ${ }^{3)}$. It is interesting to note that the time of interim test after vaccination does not affect the level of booster effects because the mean reaction size and the number of $10 \mathrm{~mm}$ or more reactors are nearly the smae in those of the different intervals, 1,2 and 2.8 years from the time of interim test to the last tests. After 5 years, however, the strong reactions in those given the first interim test at 9 weeks after vaccination left no more than that in those given no interim test At all. But the interim test at 1 or 3 years after vaccination restored or prevented waning of tuberculin sensitivity in a considerable number of individals. Another interim test produced more strong reactions than one test. Although interim tests certainly restore or prevent the waning of tuberculin reactivity in a considerabe number of dhildren, the levels never reach those of 9 weeks. This can be attributed to the fact that many strong reactors at 9 weeks became negative after some years. It is of interest that tuberculin reactions of some individuals decrease in the second test but increase again in the last test or vice versa. The increased tuberculin reaction by interim tests at 9 weeks after vaccinations seems to have resulted largely from the prevention of waning and that obtained by interim tests after 1,2 or 3 years seem to depend mostly on the restoration of tuberculin hypersensitivity. It is also of interest that negative reactors in both interim and last tests always increase with a lapse of time of the first tuberculin testing after vaccination. These findings may indicate that the tuberculin hypersensitivity of one group wanes despite interim tests, unless tuberculous infection ensues, and that of the other group wanes with a lapse of time but can be restored by interim tests and that of some last longer than the others. Whether a waned hypersensitivity, which is not restorable by tuberculin testing with 1 TU, occurrs due to weak antigenic stimulation, is not known.

As the restoration of tuberculin hypersensitivity by repeated tuberculin tests does not influence the acquired resistance in animal experiment and the degree of BCG induced protection has been found to be independent of the degree of tuberculin skin sensitivity in man, many investigators believe that revaccination policy based on tuberculin sensitivity 
is irrational ${ }^{3,7,12)}$.

\section{Summary}

The development and waning of postvaccination allergy and its restoration by interim tuberculin testing have been studied in Korean children. The freeze-dried BCG vaccine (French strain 1173 p2) elicited $10 \mathrm{~mm}$ or more reaction to $1 \mathrm{TU}$ of tuberculin RT 23 with tween in $78.3 \%$ of tuberculin negative children at 9 weeks after vaccination and their mean induration size was $12.6 \mathrm{~mm}$. After 1, 3, and 5 years, the number of $10 \mathrm{~mm}$ or more reactors was decreased to $42.1 \%, 29.9 \%$, and $27.8 \%$ respectively and the mean indurations were reduced to $7.8 \mathrm{~mm}, 6.8$ $\mathrm{mm}$, and $5.8 \mathrm{~mm}$ respectively. Such waning, however, could be prevented or restored in a large number of children by interim tuberculin testing. The interim tuberculin testing nearly doubled the number of strong reactors as opposed to those not tested until 3 or 5 years after vaccination. The strong reactors were found more often among those given two interim tests than among those given one interim test. Tuberculin reactions in some individuals ever waned despite interim tests and some increased but waned again on the subsequent tests or waned but increased again in the last tests. Negative reactions in all the sequential tuberculin tests increased as the intervals from the time of vaccination to the first interim tests widened.

\section{REFERENCES}

1) Magnus K, Edwards LB: The effect of repeated tuberculin testing on postvaccination allergy. Lancet 269 ii: 643,1955

2) Bjerkedal T, Lehmann EH: Effects of repeated tuberculin tests on skin-reactions in BCGvaccinated guinea pigs. Scand J Resp Dis 49:42, 1968

3) Guld J, Waaler H, Sundarsan TK, Kaufmann PC, ten Dam HG: The duration of BCG induced tuberculin sensitivity in children, and its irrelevance for revaccination. Bull WHO 39:829, 1968

4) Lehmann EH: The anamnestic effect in tuberculin testing: measurement and time relations, experiments in BCG-vaccinated guinea-pigs. Scand J Resp Dis 59:119, 1978

5) Magnus K: Effect of intradermal tuberculin tests on BCG-induced allergy. Bull WHO 17:249, 1957

6) Narain R, Vallishayee RS: Post vaccination allergy after three intervals of time. Bull IUAT 51:231, 1976

7) Olakowski $T$, Mardon K: The restoration influence of repeated tuberculin testing on tuberculin sensitiv. ity in BCG-vaccinated schoolchildren. Bull WHO 45: 649, 1971

8) Seth V, Kukreja N, Sundaram KR, Seth SD: Waning of cell mediated immune response in preschool children given BCG at birth. Ind J Med Res 76:710, 1982

9) Tokuchi S, Mori T: Waning of postvaccination tuberculin hypersensitivity and its restoration by tuberculin testing. Kekkaku 58:395, 1983

10) Tolderlund $\mathrm{K}$, Bunch-Christensen $\mathrm{K}$, Waaler $\mathrm{H}$ : Development and duration of BCG induced allergy in the guinea pig. Bull WHO 22:177, 1960

11) Tolderlund K, Weis Bentzon M, Bunch-Christensen K, Mackeprang B, Guld J, Waaler H: BCG-induced allergy and immunity in guinea-pigs during the first year after vaccination. Bull WHO 36: 747, 1967

12) Hart PD, Sutherland I, Thomas J: The immunity conferred by effective BCG and vole bacillus vaccines, in relation to individual variations in induced tuberculin sensitivity and to technical variations in the vaccines. Tubercle 48: 201, 1967 